\title{
Rancang Bangun Aplikasi Alat Musik Kolintang menggunakan Augmented Reality berbasis Android
}

\author{
Meylisa Rasjid. ${ }^{(1)}$, Rizal Sengkey. ${ }^{(2)}$, Stanley Karouw. ${ }^{(3)}$ \\ Informatics Engineering, Sam Ratulangi University, Manado, Indonesia. \\ Email: meylisarasjid@gmail.com, rizalsengkey@gmail.com, stanley.karouw@unsrat.ac.id.
}

\begin{abstract}
Abstrak --- Penelitian yang berjudul "Rancang Bangun Aplikasi Alat Musik Kolintang menggunakan Augmented Reality berbasis Android" ini merupakan sebuah perancangan yang bertujuan untuk menghasilkan sebuah aplikasi Augmented Reality Kolintang yang dapat berjalan pada sistem operasi android. Metode yang digunakan sebagai tahapan penelitian ini adalah metode Prototype yang merupakan metode proses perangkat lunak yang bisa memahami kebutuhan user dan dapat diperbaiki secara terus menerus sampai sesuai dengan kebutuhan user. Aplikasi yang di bangun menggunakan beberapa tools yaitu UML (Unified Modelling Language), Unity, Vuforia dan Blender3D. Maka aplikasi yang di hasilkan yaitu aplikasi augmented reality yang dapat menampilkan alat musik kolintang berbentuk 3D serta jenis suara pada setiap jenis kolintang.
\end{abstract}

Kata Kunci : Augmented Reality Kolintang, Prototype, Android

\section{PENDAHULUAN}

Perkembangan teknologi semakin pesat pada saat ini. Kemajuan ini menjadikan teknologi komputer semakin mendominasi. Dalam dunia musik pun peran teknologi komputer semakin hari semakin meningkat. Banyak masyarakat yang memanfaatkan kemajuan teknologi untuk memperkenalkan alat musik.

Kolintang atau juga biasa disebut dengan sebutan kulintang. Kata Kolintang sendiri sebenarnya berasal dari bunyi yang di hasilkan oleh alat musik tersebut yakni Tong pada saat nada rendah, Ting waktu nada tinggi dan Tang ketika mengeluarkan nada tengah. Pada zaman dulu masyarakat minahasa ketika ingin mengajak orang untuk memainkan kolintang mereka mengucapkan "Ayo kita ber TongTingTang" yang kalau dalam bahasa minahasa "Maimo Kumolintang" dari kebiasaan itulah sehingga alat musik tersebut diberi nama "Kolintang". [1]

Taman Budaya adalah gedung pertunjukan yang memadai untuk menampilkan pertunjukan-pertunjukan kesenian khas Sulawesi Utara. Tidak hanya pertunjukan kesenian yang digelar di sini, pameran dan pelatihan seni budaya juga sering digelar di taman budaya yang peresmiannya dilakukan oleh Menteri Pendidikan dan Kebudayaan Republik Indonesia saat itu Fuad Hasan. Di taman budaya ini terdapat satu gedung pertunjukan yang berukuran cukup besar untuk mementaskan pagelaran seni dan budaya. Di dukung kapasitas tempat duduk yang memadai, gedung pertunjukan ini menjadi tempat yang nyaman untuk menyaksikan sebuah pertunjukan. [2]
Penggunaan teknologi Augmented Reality dalam pengembangan aplikasi, bahwa teknologi ini dapat dijadikan alat untuk pengembangan alat musik tradisional yang lebih menarik, sehingga dapat menumbuhkan keinginan atau ketertarikan pada alat musik tradisional Kolintang sebagai warisan budaya Minahasa.

\section{LANDASAN TEORI}

\section{A. Alat Musik Kolintang}

Kolintang merupakan alat musik khas dari Minahasa (Sulawesi Utara) yang mempunyai bahan dasar yaitu kayu yang jika dipukul dapat mengeluarkan bunyi yang cukup panjang dan dapat mencapai nada-nada tinggi maupun rendah seperti kayu telur, bandaran, wenang, kakinik atau sejenisnya (jenis kayu yang agak ringan tapi cukup padat dan serat kayunya tersusun sedemikian rupa membentuk garis-garis sejajar).

Kata Kolintang berasal dari bunyi : Tong (nada rendah), Ting (nada tinggi) dan Tang (nada tengah). Dahulu Dalam bahasa daerah Minahasa untuk mengajak orang bermain kolintang: "Mari kita ber Tong Ting Tang" dengan ungkapan "Maimo Kumolintang" dan dari kebiasaan itulah muncul nama "KOLINTANG" untuk alat yang digunakan bermain.

Pada mulanya kolintang hanya terdiri dari beberapa potong kayu yang diletakkan berjejer diatas kedua kaki pemainnya dengan posisi duduk di tanah, dengan kedua kaki terbujur lurus kedepan. Dengan berjalannya waktu kedua kaki pemain diganti dengan dua batang pisang, atau kadangkadang diganti dengan tali seperti arumba dari Jawa Barat. Sedangkan penggunaan peti sesonator dimulai sejak Pangeran Diponegoro berada di Minahasa (th.1830). Pada saat itu, konon peralatan gamelan dan gambang ikut dibawa oleh rombongannya. Adapun pemakaian kolintang erat hubungannya dengan kepercayaan tradisional rakyat Minahasa, seperti dalam upacara-upacara ritual sehubungan dengan pemujaan arwah para leluhur. Itulah sebabnya dengan masuknya agama kristen di Minahasa, eksistensi kolintang demikian terdesak bahkan hampir menghilang sama sekali selama \pm 100 th.

Sesudah Perang Dunia II, barulah kolintang muncul kembali yang dipelopori oleh Nelwan Katuuk (seorang yang menyusun nada kolintang menurut susunan nada musik universal). Pada mulanya hanya terdiri dari satu Melody dengan susunan nada diatonis, dengan jarak nada 2 oktaf, dan sebagai pengiring dipakai alat-alat "string" seperti gitar, ukulele dan stringbass.

Tahun 1954 kolintang sudah dibuat 2 1/2 oktaf (masih diatonis). Pada tahun 1960 sudah mencapai 3 1/2 oktaf dengan nada 1 kruis, naturel, dan 1 mol. Dasar nada masih terbatas pada tiga kunci (Naturel, 1 mol, dan 1 kruis) dengan jarak nada 4 1/2 oktaf dari F s./d. C. Dan pengembangan 
musik kolintang tetap berlangsung baik kualitas alat, perluasan jarak nada, bentuk peti resonator (untuk memperbaiki suara), maupun penampilan. Saat ini Kolintang yang dibuat sudah mencapai 6 (enam) oktaf dengan chromatisch penuh. [3]

\section{B. Augmented Reality}

Augmented Reality merupakan salah satu trobosan yang di gunakan pada akhir-akhir ini di bidang interaksi. Penggunaan teknologi ini akan sangat membantu dalam menyampaikan suatu informasi kepada pengguna. Augmented Reality merupakan teknologi interaksi yang menggabungkan antara dunia nyata (Real Time) dan dunia maya (Virtual world).

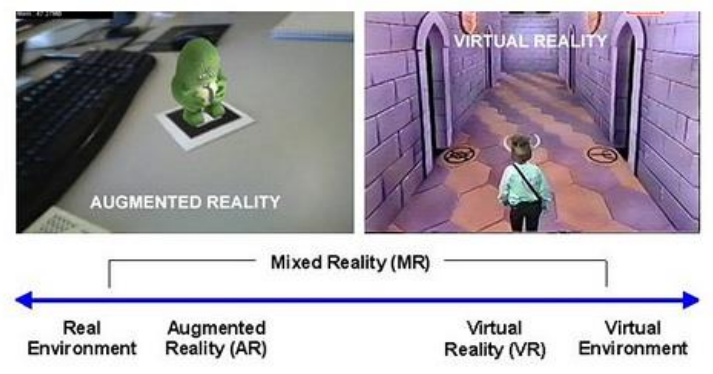

Gambar 1 Mixed Reality

Benda-benda maya menampilkan informasi yang tidak dapat diterima oleh pengguna dengan inderanya sendiri. Hal ini membuat augmented reality sesuai sebagai alat untuk membantu persepsi dan interaksi penggunanya dengan dunia nyata. Informasi yang ditampilkan oleh benda maya membantu pengguna melaksanakan kegiatan dalam dunia nyata Salah satu fitur utama dari Augmented Reality adalah media interaktif. [4]

\section{Unity $3 D$}

Unity adalah sebuah Tools yang terintegrasi untuk membuat bentuk objek 3D pada Video Games, atau untuk konteks interaktif lain seperti Visualisas Arsitektur atau animasi 3D real-time. Lingkungan dari pengembangan Unity 3D berjalan pada Microsoft Windows dan Mac Os X, serta permainan yang dibuat oleh Unity dapat berjalan pada Windows, Mac, Xbox 360, Playstation 3, Wii, iPad, iPhone, dan tidak ketinggalan pada platform Android. Unity juga dapat membuat game berbasis browser yang menggunakan Unity web player plugin, yang dapat bekerja pada Mac dan Windows, tapi tidak pada Linux. Web player yang dihasilkan juga digunakan untuk pengembangan pada widgets Mac. [5]

\section{Blender $3 D$}

Blender merupakan OSS (Open Source SOftware) atau istilah lainnya software yang dapat di gunakan di berbagai macam OS (Operating System). Ini digunakan untuk dikembangkan secara komersial, tetapi sekarang dirilis di bawah GPL (GNU General Public License). Target di profesional media dan seniman, Blender dapat digunakan untuk membuat visualisasi 3D, stills serta siaran dan video berkualitas bioskop, sedangkan penggabungan mesin 3D real-time memungkinkan penciptaan konten $3 \mathrm{D}$ interaktif untuk pemutaran yang berdiri sendiri. Blender memiliki berbagai macam kegunaan termasuk pemodelan, menjiwai, rendering, texturing, menguliti, rigging, pembobotan, editing non-linear, scripting, composite, post-produksi dan banyak lagi. [6]

\section{E. Marker/Image Target}

Marker merupakan gambar (image) dengan warna hitam dan putih dengan bentuk persegi. Dengan menggunakan marker ini maka proses tracking pada saat aplikasi digunakan, komputer akan mengenali posisi dan orientasi dari marker dan akan menciptakan objek virtual yang berupa objek 3D yaitu pada titik $(0,0,0)$ dan 3 sumbu $(\mathrm{X}, \mathrm{Y}, \mathrm{Z}) .[4]$

\section{F. Vuforia SDK}

Vuforia SDK adalah Software Development Kit berbasis AR (Augmented Reality) yang menggunakan layar perangkat mobile sebagai "lensa ajaib" atau kaca untuk melihat ke dalam dunia Augmented dimana dunia nyata dan virtual muncul berdampingan. Aplikasi ini membuat preview kamera secara langsung pada layar smartphone untuk mewakili pandangan dari dunia fisik. Object 3D akan nampak secara langsung dilayar smartphone, sehingga akan terlihat object 3D berada dalam dunia nyata, vuforia SDK terdiri dari 2 komponen utama yaitu library QCAR (Qualcomm company augmented reality) dan target management system. [7]

\section{G. Metodologi Prototipe}

Pembuatan prototipe di mulai dengan dilakukannya komunikasi antara tim pengembang perangkat lunak dengan para pelanggan. Tim pengembang perangkat lunak akan melakukan pertemuan - pertemuan dengan para stakeholder untuk mendefinisikan sasaran keseluruhan untuk perangkat lunak yang akan di kembangkan, mengidentifikasi spesifikasi kebutuhan apa pun yang saat ini diketahui, dan menggambarkan area area dimana definisi lebih jauh pada iterasi selanjutnya merupakan keharusan. Iterasi pembuatan prototipe direncanakan dengan cepat dan pemodelan (dalam bentuk "rancang cepat") di lakukan. Suatu rancangan cepat berfokus pada representasi semua aspek perangkat lunak yang akan terlihat oleh para pengguna akhir (misalnya rancangan antarmuka pengguna [user interface] atau format tampilan). Rancangan cepat (quick design) akan memulai konstruksi pembuatan prototipe. Prototipe kemudian akan diserahkan kepada para stakeholder dan kemudian mereka akan melakukan evaluasi - evaluasi tertentu terhadap prototipe yang telah dibuat sebelumnya, kemudian akhirnya akan memberikan umpan-balik yang akan digunakan untuk memperhalus spesifikasi kebutuhan. Iterasi akan terjadi saat prototipe diperbaiki untuk memenuhi kebutuhan dari para stakeholder, sementara pada saat yang sama memungkinkan kita untuk lebih memahami kebutuhan apa yang akan dikerjakan pada iterasi selanjutnya. [8]

\section{METODE PENELITIAN}

Prosedur penelitian merupakan kerangka kerja yang digunakan dalam melaksanakan penelitian. Metode prototipe memiliki tahapan-tahapan.

\section{A. Tahapan Prototipe}

Tahapan-tahapan dalam prototyping adalah sebagai berikut: 


\section{Komunikasi}

Sejumlah besar pekerjaan dan teknik yang dapat di lakukan untuk lebih memahami kebutuhan-kebutuhan biasanya dinamakan sebagai rekayasa kebutuhan. Dari sudut pandang proses perangkat lunak, rekayasa kebutuhan adalah tindakan-tindakan utama dalam kebanyakan rekayasa perangkat lunak yang bermula pada aktifitas-aktifitas komunikasi dan kemudian berlanjut ke aktifitas-aktifitas pemodelan. Pelanggan dan pengembang bersama-sama mendefinisikan format dan kebutuhan keseluruhan perangkat lunak, mengidentifikasikan semua kebutuhan, dan garis besar sistem yang akan dibuat.

\section{Perencanaan secara cepat}

Rekayasa perangkat lunak cepat menggabungkan suatu falsafah dan serangkaian tuntunan pengembangan. Falsafah tersebut mengupayakan kepuasan pelanggan dan penghantaran perangkat lunak yang meningkat; timtim proyek yang kecil dan termotivasi; metode-metode informal; produk kerja rekayasa perangkat lunak yang minimal; dan seluruh kesederhanaan pengembangan. Panduan pengembangan menekankan penghantaran daripada analisa dan perancangan (meskipun keduanya tidak diabaikan), dan komunikasi yang berlanjut dan aktif antara pengembang dan pelanggan.

\section{Pemodelan Perancangan secara cepat}

Metodologi berbasis praktik untuk pemodelan dan dokumentasi sistem berbasis perangkat lunak yang efektif. Sederhananya, pemodelan cepat adalah kumpulan dari nilai-nilai, prinsip, dan praktik untuk model perangkat lunak yang dapat diterapkan pada proyek pengembangan perangkat lunak secara efektif dan secara ringan.

\section{Pembentukan Prototipe}

Pembentukan ini dilakukan oleh pelanggan apakah prototyping yang sudah dibangun sudah sesuai dengan keinginan pelanggan. Jika sudah sesuai maka aplikasi siap di gunakan. Jika tidak, maka prototyping diperbaiki dengan mengulang langkah sebelumnya.

\section{Menggunakan Sistem}

Perangkat lunak yang telah diuji dan diterima pelanggan siap untuk digunakan.

\section{B. Unified Modelling Language (UML)}

Standard modeling language yang terdiri dari kumpulan-kumpulan diagram dan dalam pembuatan aplikasi alat musik kolintang ini tidak menggunakan semua diagram yang terdapat pada $u m l$ seperti yang sudah di jelaskan di dasar teori.

\section{Use Case Diagram}

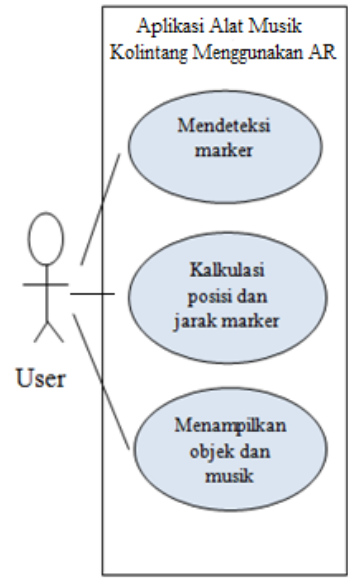

Gambar 2 Use Case Diagram

Usecase ini mendeskripsikan User pemposisikan Marker ke kamera dan sistem mengkalkulasikan posisi dan jarak marker jika sudah sesuai sistem akan menampilkan objek serta suara musik kolintang.

\section{Sequence Diagram}

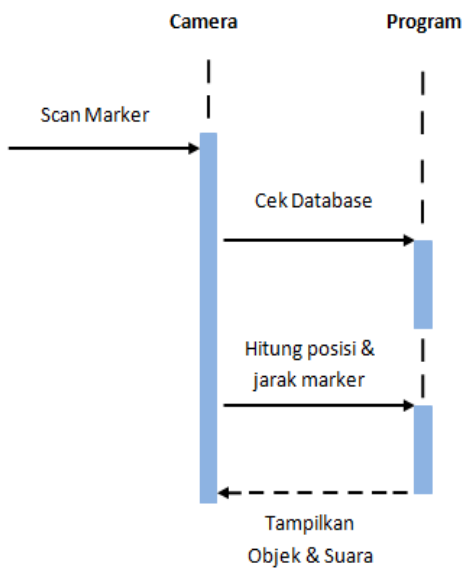

Gambar 3 Sequence Diagram

Sequence diagram dirancang untuk menunjukkan urutan aktifitas utama yang dilakukan user dan sistem dalam aplikasi Augmented Reality Alat musik Kolintang yang akan dirancang seperti gambar 3 .

\section{Class Diagram}

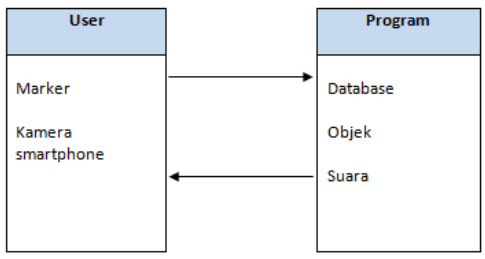

Gambar 4 Class Diagram

Class diagrampada gambar 3.23 menjelaskan bahkan user akan memposisikan marker ke kamera kemudian program akan mengecek database dan jika marker di kenali, program akan menampilkan objek serta suara dan akan di kirimkan ke layar smartphone user. 
4. Activity Diagram

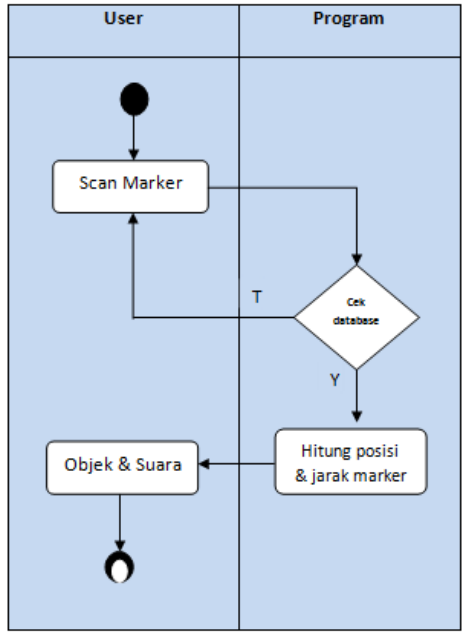

Gambar 4 Class Diagram

aktifitas dari proses yang terjadi dalam program Augmented Reality Alat Musik Kolintang yang digambarkan dengan menggunakan activity diagram dengan urutan sebagai berikut:

1. User harus memposisikan marker pada kamera.

2. Program mengecek database marker, Jika image target tidak terdapat dalam database maka objek tidak akan di tampilkan.

3. Program akan menghitung posisi dan jarak Marker.

4. Setelah marker di kenali dan menghitung posisi dan jarak maka program akan menampilkan objek dan suara di atas image target.

\section{IV.HASIL DAN PEMBAHASAN}

Membuat model alat musik Kolintang tiga dimensi dalam aplikasi blender yang akan di jadikan objek dari pembuatan aplikasi Augmented Reality alat musik Kolintang serta cara mengexport hasil modeling dan hasil desain marker.

\section{A. Marker}

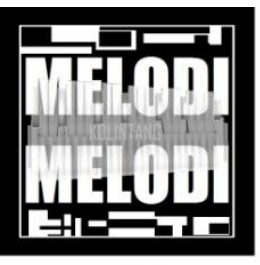

Marker Melodi

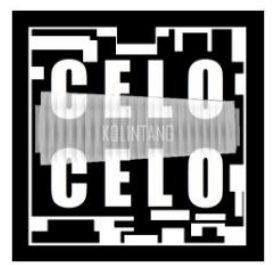

Marker Cello

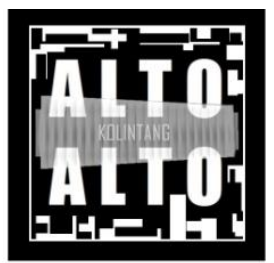

Narker Ato

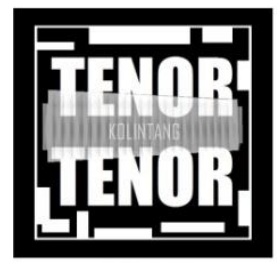

Marker Tenor
Gambar 5. Marker Kolintang 3D

Marker yang di gunakan pada aplikasi ini seperti pada gambar 5. Di desain dengan gambaran jenis kolintang pada masing-masing marker.
B. Objek Kolintang 3D

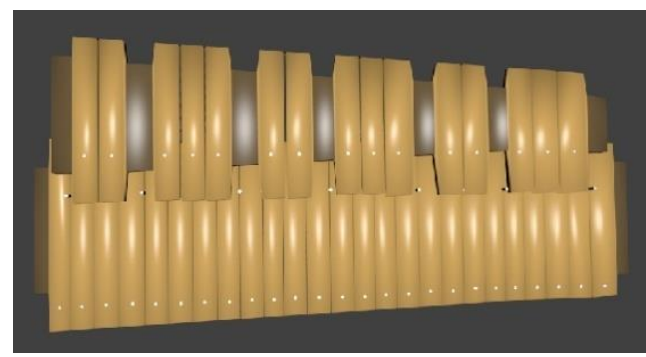

Gambar 6. Kolintang Melodi 3D

Gambar 6 adalah objek kolintang melodi 3D yang di buat di blender.

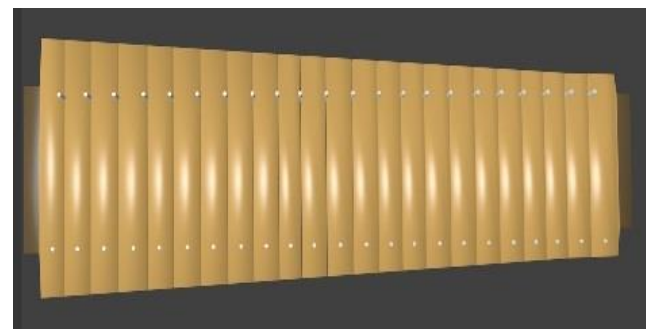

Gambar 7. Kolintang Alto 3D

Gambar 7 adalah objek kolintang alto 3D yang di buat di blender.

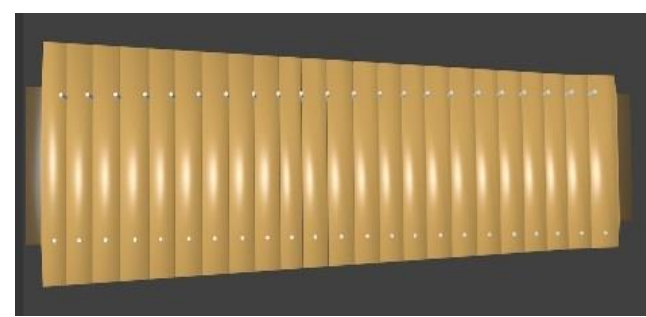

Gambar 8. Kolintang Tenor 3D

Gambar 8 adalah objek kolintang tenor 3D yang di buat di blender.

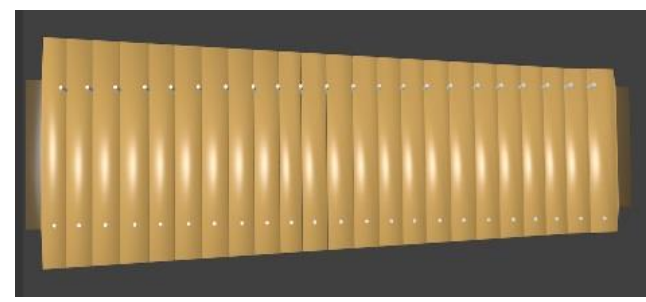

Gambar 9. Kolintang Cello 3D

Gambar 9 adalah objek kolintang cello 3D yang di buat di blender.

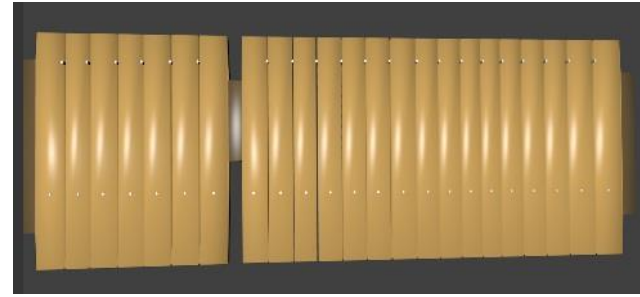

Gambar 10. Kolintang Bass 3D

Gambar 10 adalah objek kolintang bass 3D yang di buat di blender. 


\section{Menu Utama}

Pertama-tama yang harus dilakukan adalah membuka aplikasi AR (Augmented Reality) Kolintang di smartphone akan muncul tampilan menu utama dimana terdapat judul Aplikasi dan lima jenis alat musik Kolintang dan dua button yaitu About dan Quit.

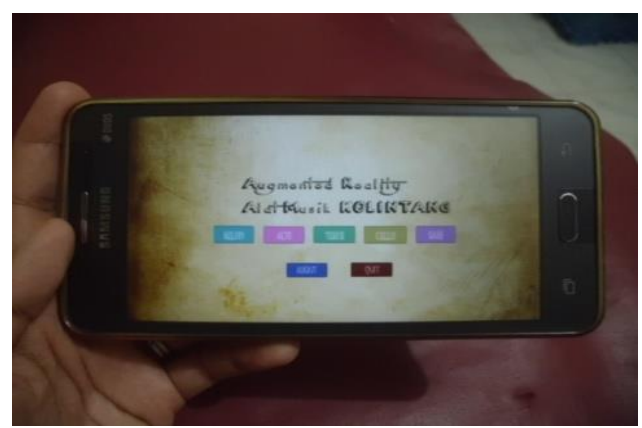

Gambar 11. Menu Utama

Gambar 11 adalah tampilan awal aplikasi augmented reality alat musik kolintang yang berbasis android.

D. Tampilan Objek dan Suara

Jika pengguna memilih button salah satu jenis kolintang maka akan menampilkan kamera yang di mana pengguna bisa memposisikan marker ke kamera dan akan menampilkan objek Kolintang serta jenis Kolintang tersebut. Scene ini juga terdapat button menu untuk kembali ke tampilan menu utama.

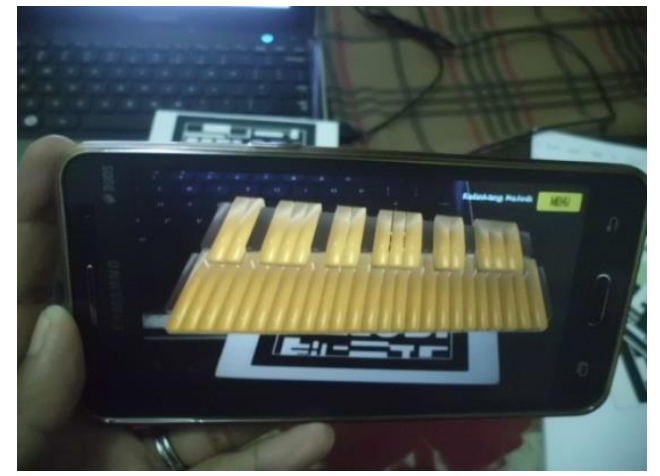

Gambar 12. Tampilan Kolintang Melodi 3D Gambar 12 menampilkan objek 3D kolintang melodi serta suara kolintang melodi.

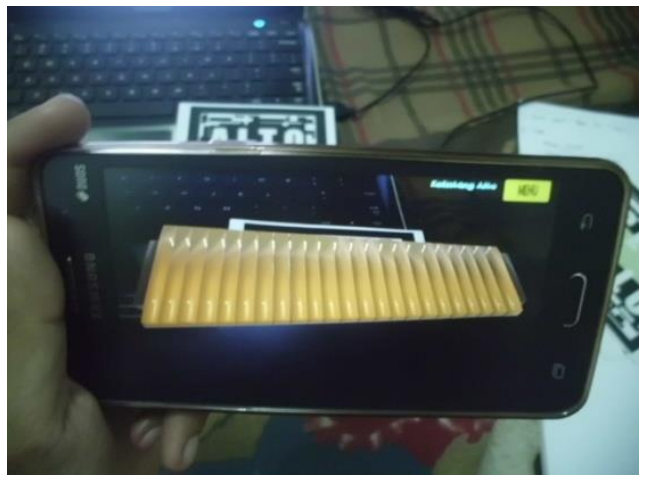

Gambar 13. Tampilan Kolintang Alto 3D Gambar 13 menampilkan objek 3D kolintang Alto serta suara kolintang Alto.

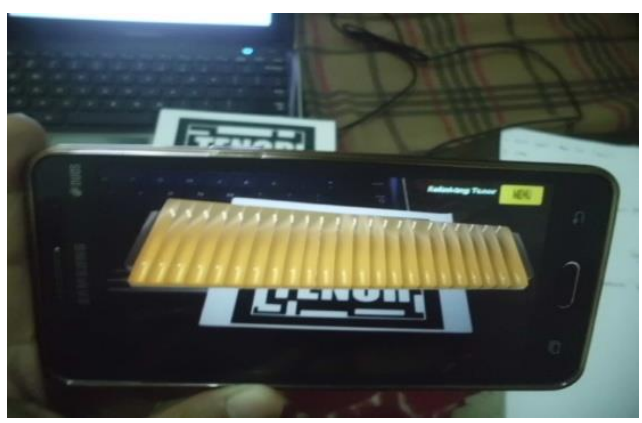

Gambar 14. Tampilan Kolintang Tenor 3D Gambar 14 menampilkan objek 3D kolintang Tenor serta suara kolintang Tenor.

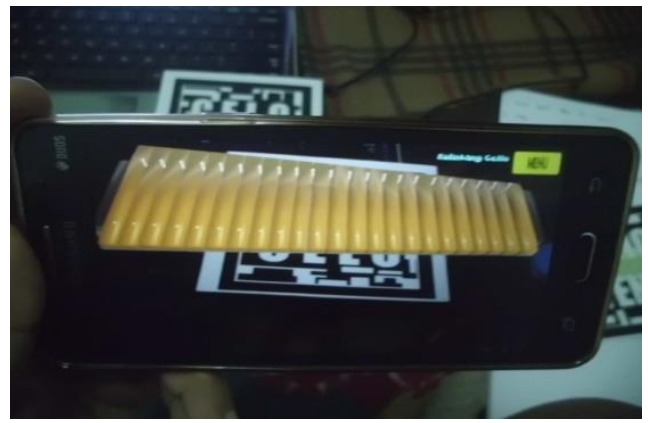

Gambar 15. Tampilan Kolintang Cello 3D Gambar 15 menampilkan objek 3D kolintang Cello serta suara kolintang Cello.

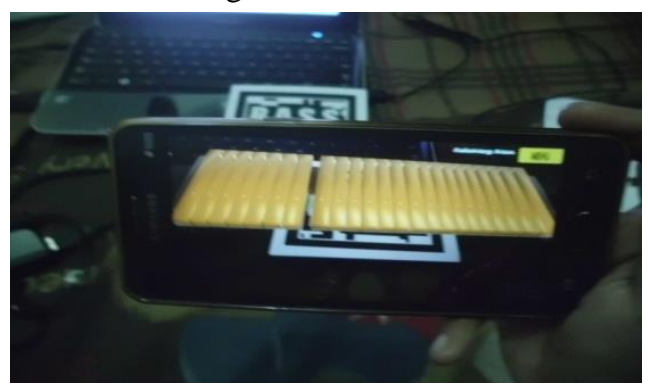

Gambar 16. Tampilan Kolintang Bass 3D

Gambar 16 menampilkan objek 3D kolintang Bass serta suara kolintang Bass.

\section{E. Tampilan Informasi}

Pengguna juga bisa melihat informasi dari aplikasi Augmented Reality Alat Musik Kolintang yang hanya menampilkan informasi sederhana seperti pada gambar 7 .

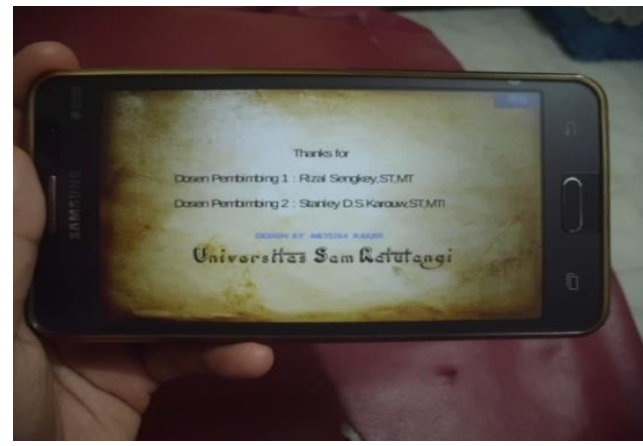

Gambar 17. Scene Informasi

Proses menjalankan aplikasi telah selesai. Di akhiri dengan menekan button Quit yang terdapat di menu utama. 


\section{F. KESIMPULAN}

Kesimpulan yang dapat diberikan dari pembuatan Augmented Reality Alat Musik Kolintang ini adalah sebagai berikut:

a. Menghasilkan Augmented Reality Alat Musik Kolintang berbasis Android.

b. Objek 3D berhasil di import dari Blender yang kemudian dijadikan Augmented Reality Object dalam Unity.

c. Penulis juga memanfaatkan fitur AR Camera, Image Target dan Script Editor.

d. Lebih Melestarikan Alat Musik Kolintang dan Kebudayaan Minahasa dengan menggunakan Media Augmented Reality.

\section{DAFTAR PUSTAKA}

[1.] http://www.alatmusiktradisional.com

[2.] http://www.indonesiakaya.com

[3.] Salena Donny Putra, (2011), "Makalah Seni Musik Tradisional", Man Babat, Pamekasan Madura

[4.] Iwan Setya Nugraha, (2009), "Pemanfaatan Augmented Reality untuk pembelajaran pengenalan alat musik piano" Program studi sistem komputer, Fakultas Teknik, Universitas Diponegoro

[5.] Evans Winanda Wirga, Cindy putri pungkasanthi, (2012),'Pembuatan Aplikasi Augmented Reality book berbasis Android menggunakan Unity 3D", Jurusan Teknik Informatika, Fakultas Teknologi Industri, Universitas Gunadarma.

[6.] Gede Ngurah Arya Indrayasa, (2014),"Analisis, perancangan dan penerapan Computer Generated Imagery (CGI) dalam pembuatan modeling 3D "Realistic Human Head" menggunakan Blender 2.68", Sekolah Tinggi Manajemen informatika dan komputer, AMIKOM Yogyakarta

[7.] Fajar, Febriyan (2014). "Mobile Interactive Augmented Reality" Buku 1. Solo : Dhika Prihantono

[8.] Roger S. Presman, 2012. Rekayasa Perangkat Lunak Pendekatan Praktisi Edisi 7 - Buku 1.

Yogyakarta:Andi

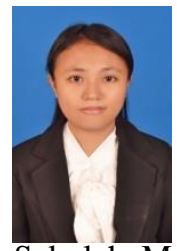

Sekilas dari penulis dengan nama lengkap Meylisa Rasjid, lahir pada tanggal 27 Mei 1992 di kota Manado Sulawesi Utara. Anak Pertama dari 2 bersaudara dengan memulai pendidikan sekolah dasar di SD Negeri 01Manado.

Kemudian pada tahun 2004 melanjutkan ke Sekolah Menengah Pertama SMP Negeri 03 Manado dan pada tahun 2007 melanjutkan ke SMK Negeri 03 Manado. Setelah lulus pada tahun 2010 penulis melanjutkan ke Perguruan Tinggi tepatnya di Universitas Sam Ratulangi Manado dengan mengambil jurusan Teknik Informatika. Pada tahun 2015 bulan Februari penulis membuat skripsi demi memenuhi syarat sarjana (S1) dengan penelitian yang berjudul Rancang Bangun Aplikasi Alat Musik Kolintang menggunakan Augmented Reality berbasis Android yang di bimbing oleh kedua dosen Teknik Informatika Rizal Sengkey, ST, MT dan Stanley D.S Karouw, ST., MTI sehingga pada tanggal 19 Januari 2016 penulis resmi lulus di Teknik Informatika Universitas Sam Ratulangi dan menyandang sebagai Sarjana Komputer. 